\title{
EFFECTIVENESS OF INTERVENTIONS CO-FINANCED BY THE EU STRUCTURAL FUNDS IN WIELKOPOLSKA IN THE YEARS 2004-2006
}

\author{
PAWEe CHURSKi \& ANNA BorowczaK \\ Adam Mickiewicz University, Institute of Socio-Economic Geography and Spatial Management, \\ Poznań, Poland \\ Manuscript received May 15, 2010 \\ Revised June 11, 2010
}

CHURSKi P. \& BorowcZaK A., Effectiveness of interventions co-financed by the EU structural funds in Wielkopolska in the years 2004-2006. Quaestiones Geographicae 29(2), Adam Mickiewicz University Press, Poznan. 2010, pp. 85-102, 3 Tables. ISBN 978-83-232-2168-5. ISSN 0137-477X. DOI 10.2478/v10117-010-0016-3.

AвSTRACт. The aim of this article is to analyse the effectiveness of interventions from the EU Structural Funds in Wielkopolska carried out for investments realised in the years 2004-2006, i.e. in the first period of implementing Community regional policy in Poland. The research procedure is composed of two fundamental stages. In the first, projects co-financed from the EU Structural Funds within the framework of the Regional Component of the Integrated Regional Operational Programme were systematised by the criterion of intervention direction within each of the three dimensions of cohesion: economic, social and territorial. In the second stage, selected diagnostic measures for each dimension of cohesion were subjected to effectiveness analysis. The procedure rested on a questions/methods-oriented model applied in line with the theory-driven evaluation approach, a quasiexperimental design and the difference-in-differences technique, as well as methods of econometric analysis. The results made it possible to assess public intervention in Poland in terms of its effectiveness, and to identify challenges that have to be faced very soon.

KEYWORDS: evaluation of effectiveness, cohesion, Structural Funds

Pawet Churski, Anna Borowczak, Regional Analysis Department, Institute of Socio-Economic Geography and Spatial Management, Adam Mickiewicz University; ul. Dzięgielowa 27, 61-680 Poznań, Poland; e-mail: chur@amu.edu.pl; anna. borowczak@amu.edu.pl

\section{Introduction}

European cohesion policy is a subject of an increasing dispute between its advocates and adversaries. Supporters present it very often as the greatest experiment in the field of public intervention, an act of solidarity between Member States of the European Union. Opponents, in turn, undermine its effectiveness and economic rationale by attracting attention to wasted possibilities of sectoral intervention. A report delivered by Fabrizio Barca, the recent EU budget review and the project of the Europe 2020 strategy intensify this stormy debate providing all discussants with new arguments. One of the most highlighted priorities is now more effec- 
tive measures optimising the steering of cohesion policy aimed at effective improvement in all of its three dimensions: economic, social and territorial. Their basis is to be an intensification of evaluation of the intervention intended. The problem is of paramount significance in the new Member States, especially in Poland as the largest beneficiary of the EU Structural Funds. Considerable inputs of structural funds are frequently associated with an uncertainty as to whether the expensive interventions funded by EU taxpayers are properly targeted and whether they are an important factor improving the cohesion of the Polish regions.

The aim of this article is an analysis of directions and effectiveness of structural interventions in Wielkopolska, carried out for investments implemented in the years 2004-2006, i.e. during the first period of implementation of EU regional policy in Poland. The evaluation of public intervention is conducted within three dimensions of cohesion and exemplified with the Integrated Regional Operational Programme (IROP), which was the main instrument of Polish regional policy in the financial perspective 2004-2006. The cornerstone of this analysis is an attempt to determine differences in the effectiveness of intervention granted from the EU Structural Funds in shaping the relevant dimensions of cohesion in Wielkopolska voivodeship. The article is composed of three basic parts. The first presents the origin of regional policy evaluation and vital challenges that its development faces. In the second, main streams of regional policy intervention are systematised in terms of the three dimensions of cohesion. The third part contains the results of an empirical analysis of the effectiveness of Structural Fund interventions in Wielkopolska.

The system of spatial units used in the research is the set of communes (LAU-2) and poviats (LAU-1) of Wielkopolska voivodeship. Due to limited accessibility of statistical data, the effectiveness of public intervention in shaping economic and social cohesion is analysed for a set of 226 communes, and in the case of territorial cohesion - for 35 poviats. The data used in the analysis come from published and unpublished databases of the Central Statistical Office and refer to the years 2003-2008.

\section{Evaluation of regional policy}

Evaluation derives from the public administration management practice applied in the United States. Some authors, including Stufflebeam et al. (2000), seek its origins in studies on the efficiency of the educational system in Anglo-Saxon countries in the mid-19 ${ }^{\text {th }}$ century, which were subsequently developed in the 1930s, but actual progress in this realm was only made in the 1960s (Shadish et al. 1991). An increase of interest in evaluation was strongly connected with generously funded federal programmes presented by the US President Lyndon Johnson under the banner of 'Great Society' in $1965 .^{1}$ The engagement of a large federal budget in the implementation of this intervention forced the US government to monitor the effectiveness of public money spending. The specific directions of federal investment along with former research conducted in the public education sector decided that the evaluation practice of this period developed mainly within social science, and the biggest progress was noted in evaluation of educational programmes.

A special role in the dissemination of evaluation practices in Europe was played by the reform of regional policy in $1988 .^{2}$ The provisions of the Single European Act (1986), confirmed in the Treaty of Maastricht (1992), emphasised very definitely the effectiveness of the new regional policy, therefore a formal obligation to conduct evaluations of structural programmes was imposed on the Member States in the first regulation for the financial perspective 1989-1994 (European Commission 2007). However, for many Member States this challenge turned out to be too difficult to meet. As a consequence, in the 1990s the European Commission launched a research

\footnotetext{
${ }^{1}$ The programmes aimed at a mitigation of mounting social tension by enhancing accessibility to public services, e.g. education, health-care, transport, etc.

${ }^{2}$ As Bachtler (2008) notes, an increase in state intervention in the 1960s was also visible in Europe and contributed to the development of evaluation practices, especially in the Scandinavian countries, Germany, the Netherlands, and the U.K., i.e. in countries either with strong democratic participation or strong connections with the USA or Canada. In these countries evaluation has been practised since the 1970s. The other European countries, particularly from the south of Europe, were forced to adopt evaluation practices by the EC regulations of 1988 introduced as part of a regional policy reform (cf. Bachtler \& Wren 2006).
} 
project known under its French acronym MEANS (Methods for Evaluating Actions of a Structural Nature). The work bore fruit in 1999 when a six-volume handbook on evaluation of structural funds was published. The expanding application spectrum of evaluation as well as a shift in the approach towards modern public administration contributed to a permanent inclusion of evaluation into the system of public intervention management in advanced countries (Bachtler \& Wren 2006; Olejniczak 2008).

Currently the term 'evaluation' is dedicated to commonly applied socio-economic research verifying the effectiveness and efficiency of public intervention implemented. According to the American standards adopted and developed for the European conditions, evaluation studies should be carried out in a strictly systematic way and should lead to an assessment of the quality and worth of public intervention as reflected in economic and financial terms (cf. Sanders 1994). It should be emphasised that the superior objective of evaluating public intervention lies in ensuring the applicability of its results to public administration activities (Alkin 2004). The aspect of utility of an evaluation study is also confirmed in the definition adopted by the World Bank (Independent Evaluation Group... 2008), which states that an evaluation should lead to conclusions and/or recommendations improving future intervention. Intense pressure on the applicability of evaluation results remains significant for the methodological foundations of studies undertaken. The results is a kind of research eclecticism characterised by much arbitrariness in the choice of criteria and methods, which leads to the conclusion that evaluation often exceeds the framework of a strictly scientific research (Olejniczak $2008)^{3}$.

\footnotetext{
${ }^{3}$ It is worth mentioning that the several decades of theoretical reflections and intense empirical studies have resulted in a comprehensive literature on evaluation, which is emerging as a separate field of research for representatives of various disciplines of science. A classification of the main directions in the theoretical discourse on evaluation research might look as follows: (1) theories of use, (2) methodology, and (3) theories of valuating. In each of those fields, evaluation largely derives from the output of social science, e.g. rules of designing and implementing public policies, methods of social research, etc. Much attention is devoted to ontology and epistemology (Shadish et al. 1991; Alkin 2004).
}

The methodological imperfections of evaluation are proved by the fact that despite frequent references to various theories made in the literature of the subject, there is actually no theory of evaluation meeting the formal requirements of this notion (Alkin 2004). Rather, it seems to be more justified to employ terms such as 'model' or 'approach'. Stufflebeam et al. (2000) recognise three main models of evaluation:

1. a questions/methods-oriented model,

2. an improvement/accountability-oriented model, and

3. a social agenda/advocacy approaches.

The growing scope of applicability of evaluation, now also covering regional policy intervention, has naturally enlarged the range of scientific inspirations in this field. In this context, the practice of evaluation research can find special use for such relatively new tools in this type of study as methods of spatial analysis and cartographic visualisation employing geographic information systems, apart from adapting the necessary theoretical background underlying the regional development paradigm. The systematic increase in the role of evaluation in managing EU regional policy enlivens the methodological discussion. One of the key challenges facing modern regional policy is to deliver measurable and reliable results justifying the continuation of intervention based on the concept of the primacy of regional policy over sectoral ones that has been in force since 1988. The problems that regional policy evaluation has to cope with today are not only further improvement of the methodology and system of statistical data monitoring to ensure their best comparability possible, but also a critical reflection on the following issues (Dutkowski 2008) :

1. What is the conceptual scope of 'cohesion' and what is its meaning in regional policy?

2. What evaluation criteria should be used and in what reference systems?

3. What should be the relationship between an evaluation of intervention and an evaluation of its effects?

\section{Cohesion and regional policy measures}

The term cohesion is inseparably connected with regional policy. The superior objective of 
regional policy perceived as a form of state intervention in the development process is to improve the level of socio-economic development, thus leading to an improvement in the population's standards and conditions of living. Measures undertaken for this purpose, especially in the case of the EU Member States, are directly linked with efforts to increase cohesion (Green Paper ... 2008; Barca 2009; Reshaping ... 2009; Samecki 2009; Polityka spójności ... 2010; Europa 2020...2010).

The concept of cohesion is used in European regional policy to determine the level of divergence between countries or regions, and so far it has involved endeavours to level out those differences through stimulation of development processes. The development of the concepts of various dimensions of cohesion, from economic, through social to territorial, has its origins in the legal foundations of the European Communities, beginning with the Single European Act and the Maastricht Treaty to the Amsterdam Treaty and recently the Lisbon Treaty (Parysek 2008; Churski 2009a). Distinguishing the three dimensions of cohesion in the framework of the EU cohesion policy is connected with relating cohesion to some relevant aspects of socio-economic life. While the present study is restricted to the most important ones: economic, social and territorial ${ }^{4}$, it has to be stressed that contemporary discourse on those three dimensions has to comprise consequences of changes in the modern paradigm of development and regional policy. Lack of expected efficiency and effectiveness of regional policy, if narrowed solely to the compensation paradigm in each of the three distinguished dimensions, causes the discussion about future regional policy to shift to the necessity of considering a functional approach to cohesion (Green Paper ... 2008). It should be emphasised, as is also done by e.g. Gorzelak (2009), that cohesion understood as a compensation tool leads to a contradiction resulting from the classic regional policy dilemma: equality or efficiency. Functional cohesion in its three dimensions: economic, social and territorial, boosts the competitiveness of an area perceived as a grand total of the competitiveness

\footnotetext{
${ }^{4}$ It should be noted that there are also other dimensions of cohesion distinguished in the literature, e.g. cultural, ethnic, political, etc.
}

of all enterprises and their surroundings. ${ }^{5}$ Such an approach, however, requires the assumption that cohesion need not necessarily mean a state where differences are levelled out, but merely a state where they are politically and socially acceptable. It is worth stressing that the functional approach to cohesion is directly enclosed in postulates of the Lisbon Strategy and the Europe 2020 strategy. Sustainable cohesion can only be reached through competitiveness and economic growth based on innovativeness and applied knowledge, whereas an improvement in cohesion is a condition of boosting the competitiveness and economic growth. It is vital especially at the regional level, where intervention within the framework of cohesion policy aims at full employment of the regional and local resources of growth that now decide about the productivity of the economy and enable improving the socio-economic cohesion of the entire European Union through increasing the competitiveness of regions (Faludi 2006).

When adopting the functional approach to cohesion, the main differences between its three dimensions have to be identified (Churski 2009a)

Economic cohesion is the dimension connected with the mitigation of differences in socio-economic development. In the functional approach, the superior objectives of economic cohesion is to: "... harmonise the operation of the whole economic system and make possibly full use of the potential of its components" (Gorzelak 2009, p: 14). At the regional level, economic cohesion can be interpreted as related with the level of socio-economic development of the given area resulting from the state and structure of the economy, the level of development of economic infrastructure, the financial situation of economic entities and their surroundings, as well as innovativeness and productivity. A vital element of improvement in economic cohesion in its functional aspect is creating favourable conditions for the development of business networks to optimise conditions for the use of endogenous

${ }^{5}$ Cohesion lowers transaction costs for enterprises, which take advantage of well-functioning transport and communication linkages, a developing institutional support, and mobile workforce resources characterised by a high level of social and human capital. 
TABle 1. OBJECTIVES AND MEASURES OF REgIONAL POLICY AND ECONOMIC, SOCIAL AND TERRITORIAL COHESION

\begin{tabular}{|c|c|c|}
\hline $\begin{array}{l}\text { Dimensions of } \\
\text { cohesion }\end{array}$ & Objectives and measures of regional policy & Scope of intervention: examples \\
\hline Economic & $\begin{array}{l}\text { - } \text { creating conditions for development of } \\
\text { entrepreneurship } \\
\text { - improving investment attractiveness } \\
\text { - improving state and structure of business } \\
\text { support framework, including development } \\
\text { of financial instruments available to } \\
\text { enterprises } \\
\text { - improving state of infrastructure for } \\
\text { enterprises } \\
\text { - improving state of infrastructure for } \\
\text { - } \text { devriculture and rural areas } \\
\text { - economing tourism and recreation in } \\
\text { improving innovativeness of business } \\
\text { - imprivities } \\
\text { activities }\end{array}$ & $\begin{array}{l}\text { - } \text { projects supporting development of SMEs } \\
\text { and micro-enterprises } \\
\text { - } \text { projects supporting construction and } \\
\text { expansion of infrastructure for investment } \\
\text { areas } \\
\text { - } \text { projects of development of business support } \\
\text { institutions } \\
\text { - } \text { projects of development of business services } \\
\text { - } \text { projects of development of industrial } \\
\text { infrastructure } \\
\text { - } \quad \text { projects of development of farm } \\
\text { infrastructure and automation of food } \\
\text { management } \\
\text { - projects of development of tourism and } \\
\text { - } \text { recreation activities } \\
\text { projects of development of innovation } \\
\text { activities } \\
\text { projects enhancing productivity of business } \\
\text { activities }\end{array}$ \\
\hline Social & $\begin{array}{l} \\
\text { - improvement of state and structure of } \\
\text { - } \text { improvement of state and structure of social } \\
\text { - } \text { capital } \\
\text { - } \text { munelopment and modernisation of } \\
\text { - improvement of access to human services } \\
\text { - improvement of housing conditions } \\
\text { management of environment and rational }\end{array}$ & 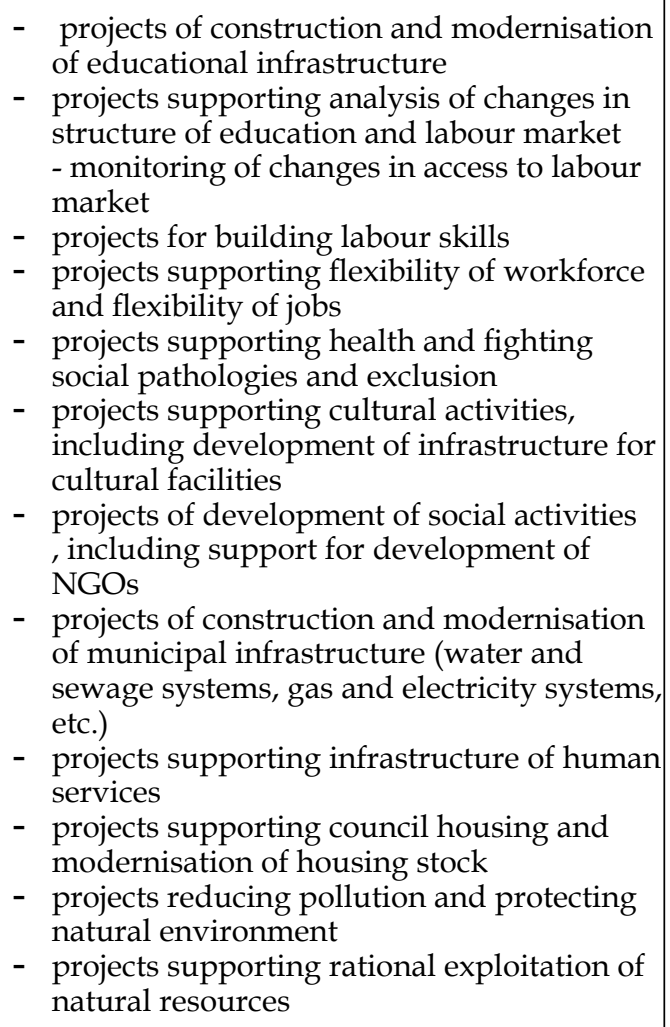 \\
\hline Territorial & $\begin{array}{l}\text { - development and modernisation of } \\
\text { transport infrastructure } \\
\text { - development and modernisation of wireless } \\
\text { and Internet communications infrastructure } \\
\text { - urban renewal }\end{array}$ & $\begin{array}{l}\text { - projects of construction and modernisation } \\
\text { - po road and rail networks } \\
\text { - projects of modernisation of rolling stock } \\
\text { - projects of construction and modernisation } \\
\text { of communications infrastructure, including } \\
\text { broadband Internet network } \\
\text { - projects of revitalisation of urban space }\end{array}$ \\
\hline
\end{tabular}

Source: own compilation.. 
resources of the particular regions and bettering their investment climate. ${ }^{6}$

Social cohesion refers to the ability of a society to ensure welfare to all its citizens, minimise the disparities among them, and avoid social polarisation (Karwacki 2009). In the functional approach to this dimension, the most relevant measures are those seeking to create co-operation networks based on social skills and teamwork capabilities, which can create similar standards and conditions of living for all inhabitants by using information society technologies, even in the conditions of an irregular distribution of social infrastructure and jobs. At the regional level, social cohesion can be interpreted in relation with the level of social development of the area in terms of the accessibility of the labour market, standards and conditions of living deriving from the income level, and social bonds. A crucial element improving social cohesion in its functional aspect is the creation of conditions for development of social participation aimed at increasing the level of citizen involvement in social life.

Territorial cohesion is of a complementary character, strengthening the economic and social cohesion. Territorial cohesion, especially in functional terms, is not only a tool but also an effect of achieving economic and social cohesion. It is a necessary condition for shaping the development process in accordance with the polarisation-diffusion model (Growing Regions ... 2007; Churski 2009a). At the regional level, territorial cohesion should be identified as a network structure of a region that allows an increase in cohesion in economic and social aspects and enables rational performance of the socio-economic system. Therefore, territorial cohesion is largely connected with a system of linkages that enable the development of functional relations occurring in the economic and social dimensions and that ensure complementarily to the regional system. An analysis of territorial cohesion should focus on the state of development and structure of the settlement network and communications infrastructure, the components that give a regional economy its functional foundation. Intervention improving transport, ICT and urban infrastructure, i.e. basic conditions for a region to

${ }^{6}$ Special significance in this field is attributed to establishing, e.g., business information and co-operation databases, innovation networks, and economic clusters. develop network organisation, is interpreted as a measure supporting territorial cohesion.

Considering the circumstances of development processes in Poland as well as measures taken within the framework of regional policy, an attempt can be made to systematise the directions of intervention granted in terms of the three dimensions of cohesion (Churski 2009b; 2009c) (Table 1). The classification provides a basis for evaluating the efficiency of intervention carried out under the Integrated Regional Operational Programme (2004) in Wielkopolska voivodeship, which is the chief goal of this paper.

\section{Evaluation of IROP intervention in terms of the three cohesion dimensions}

The evaluation of public intervention cofinanced from the EU Structural Funds carried out in this article is exemplified by the Integrated Regional Operational Programme (IROP), which was the main instrument of regional policy in Poland in the financial perspective 2004-2006. What prove its significance for the policy are its biggest share in the financial outlays for the National Development Plan 2004-2006 (2003)/ Community Support Framework 2004-2006 (2003), and its regional targets. The IROP was managed at the central level, but a huge part of its implementation was conducted at the regional level on the basis of the Regional IROP Components prepared for each of the 16 voivodeships. This solution was only temporary. It aimed at preparing Polish regions for independent development and execution of Regional Operational Programmes, which takes place in the current perspective 2007$2013^{7}$. The present analysis refers to the Regional IROP Component for Wielkopolska voivodeship, the implementation of which terminated in June 2009. This should theoretically make it possible to conduct an ex-post evaluation, but turned out to be extremely difficult due to serious limitations in the accessibility of current data. ${ }^{8}$ The indica-

\footnotetext{
${ }^{7}$ More on IROP implementation in the Polish regions in Churski $(2008,2010)$.

${ }^{8}$ This analysis does not constitute a full ex-post evaluation of the Operational Programme or any of its diagnostic measures because it focuses solely on the effectiveness of intervention, one of the five standard evaluation criteria required by the European Commission.
} 
tive allocation of the funds granted to Wielkopolska under the IROP amounted to 876 million zlotys (196 million euros $\left.{ }^{9}\right)$, which ranked the region 5th in the country in the share of total allocation $(7.1 \%$ of the Structural Funds in the national IROP budget) and 14th in terms of the sum granted per capita (50.1 euros from the IROP budget per voivodeship inhabitant) (Churski 2008). The IROP implemented in Wielkopolska included all the priorities set at the national level with the following division of the structural means:

- PRIORITY I (58.6\% of Structural Funds allocation): Development and modernisation of infrastructure enhancing the competitiveness of regions

- PRIORITY II (16.6\% of Structural Funds allocation): Strengthening human resources development in regions

- PRIORITY III (24.8\% of Structural Funds allocation): Local development

The main IROP beneficiaries in Wielkopolska were predominantly territorial self-governments (79\% of total funding), enterprises, educational institutions, health-care institutions, non-governmental organisations, churches, and R\&D institutions. Projects co-financed from the IROP funds included, e.g., the construction and modernisation of roads $(37 \%)$, the construction and modernisation of sewage treatment plants $(26 \%)$, and the development of social and health-care infrastructure (16\%) (Wykorzystanie ZPORR... 2009; Stan wdrażania ZPORR...2009).

The evaluation of public intervention under the Regional IROP Component in Wielkopolska is conducted following the assumptions of the questions/methods-oriented model using a theory-driven evaluation approach, a quasi-experimental design, and the difference-in-differences technique. The research procedure is composed of three stages.

In the first stage, a systematisation of Priorities and Measures of the Regional IROP Component 2004-2006 in Wielkopolska was made on the basis of the presented set of three dimensions of cohesion. The results made it possible to determine the directions of intervention and outlays devoted to increasing cohesion in Wielkopolska

${ }^{9}$ The exchange rate adopted in this article is that of 4.4696 zlotys to the euro (the National Bank of Poland's average as of 30th June 2009). in the particular dimensions. Each of the IROP priorities was implemented via multidirectional measures intended to boost cohesion in more than just one dimension. In the case of the economic and social cohesion, the intervention measures undertaken to improve them were implemented under all the priorities, while territorial cohesion was supported within the framework of PRIORITY I, Development and modernisation of infrastructure to enhance the competitiveness of regions, and PRIORITY III, Local development. Most funds were assigned to an improvement of social cohesion and the smallest outlays went to support economic cohesion. In terms of intervention concentration, the smallest number of projects but of the highest worth were implemented under measures improving territorial cohesion (an average project value of over 5 million zlotys, or 1.1 million euros). The most dispersed was intervention supporting economic cohesion, with an average project value of under 450 thous. zlotys (approx. 100 thous. euros; see Table 2).

In the second stage, some diagnostic measures implemented under the IROP in Wielkopolska were selected for further analysis. It was assumed that two diagnostic measures should be chosen for each dimension of cohesion: one that exerts a positive influence on the relevant cohesion dimension due to its dominating share in the financial inputs, and another that, in the authors' opinion, should improve it to the largest extent considering the theoretical assumptions of the conception of the three dimensions of cohesion. The result was a six-element matrix composed of 3 dimensions of cohesion $x 2$ diagnostic measures, described with statistical indicators in the next stage.

In the third stage of the research procedure carried out according to the theory-driven evaluation approach, further analysis rested on the theory of change, which enables the identification of the cause-and-effect mechanism determining the relation between various categories of public intervention results. ${ }^{10}$ According to the theory of change, it is assumed that the results of intervention should be considered in three aspects: direct results, interim results, and long-term results. A direct result is the anticipated effect of

${ }^{10}$ For more on this topic, see Chen (1990), Stufflebeam et al. (2000), Olejniczak (2009). 
Table 2. Integrated Regional Operational Programme 2004-2006 - implementation of the Programme and Dimensions OF COHESION (AS OF August 31st 2009*)

\begin{tabular}{|c|c|c|c|c|c|}
\hline $\begin{array}{l}\text { Dimension } \\
\text { of cohesion }\end{array}$ & PRIORITY & Measure / Sub-measure & $\begin{array}{c}\text { No. of } \\
\text { projects }\end{array}$ & $\begin{array}{l}\text { Co-financing } \\
\text { from structural } \\
\text { funds }\end{array}$ & $\begin{array}{l}\text { Total value of } \\
\text { projects }\end{array}$ \\
\hline \multirow[t]{3}{*}{ Economic } & $\begin{array}{l}\text { PRIORITY I: } \\
\text { Development and } \\
\text { modernisation } \\
\text { of infrastructure } \\
\text { to enhance } \\
\text { competitiveness of } \\
\text { regions }\end{array}$ & $\begin{array}{l}\text { 1.4 Development of } \\
\text { tourism and culture }\end{array}$ & $\begin{array}{c}18 \\
(2.3 \%)\end{array}$ & $\begin{array}{l}74,475,323.23 \\
\text { zlotys } \\
(7.8 \%)\end{array}$ & $\begin{array}{l}115,228,535.10 \\
\text { zlotys } \\
(7.6 \%)\end{array}$ \\
\hline & $\begin{array}{l}\text { PRIORITY II: } \\
\text { Strengthening } \\
\text { human resources } \\
\text { development in } \\
\text { regions }\end{array}$ & $\begin{array}{l}2.6 \text { Regional innovation } \\
\text { strategies and transfer of } \\
\text { knowledge }\end{array}$ & $\begin{array}{c}43 \\
(5.4 \%)\end{array}$ & $\begin{array}{l}11,817,735.80 \\
\text { zlotys } \\
(1.2 \%)\end{array}$ & $\begin{array}{c}15,665,795.80 \text { zlo- } \\
\text { tys } \\
(1.0 \%)\end{array}$ \\
\hline & $\begin{array}{l}\text { PRIORITY III: } \\
\text { Local development }\end{array}$ & 3.4 Micro-enterprises & $\begin{array}{c}156 \\
(19.9 \%)\end{array}$ & $\begin{array}{c}8,518,584.24 \text { zlo- } \\
\text { tys } \\
(0.9 \%)\end{array}$ & $\begin{array}{c}32,796,527.32 \text { zlo- } \\
\text { tys } \\
(2.1 \%)\end{array}$ \\
\hline \multicolumn{3}{|l|}{ TOTAL: } & $\begin{array}{c}217 \\
(27.6 \%)\end{array}$ & $\begin{array}{l}94,811,643.27 \\
\text { zlotys } \\
(9.9 \%)\end{array}$ & $\begin{array}{c}163,690,858.20 \\
\text { zlotys } \\
(10.7 \%)\end{array}$ \\
\hline \multirow[t]{6}{*}{ Social } & $\begin{array}{l}\text { PRIORITY I: } \\
\text { Development and } \\
\text { modernisation } \\
\text { of infrastructure } \\
\text { to enhance } \\
\text { competitiveness of } \\
\text { regions }\end{array}$ & $\begin{array}{l}\text { 1.2 Environmental } \\
\text { protection } \\
\text { infrastructure }\end{array}$ & $\begin{array}{c}19 \\
(2.4 \%)\end{array}$ & $\begin{array}{l}105,909,928.30 \\
\text { zlotys } \\
(11.0 \%)\end{array}$ & $\begin{array}{c}170,142,987.90 \\
\text { zlotys } \\
(11.2 \%)\end{array}$ \\
\hline & & $\begin{array}{l}\text { 1.3 Regional social } \\
\text { infrastructure } \\
\text { 1.3.1 Regional educational } \\
\text { infrastructure } \\
\text { 1.3.2 Regional health-care } \\
\text { infrastructure }\end{array}$ & $\begin{array}{c}28 \\
(3.6 \%)\end{array}$ & $\begin{array}{l}90,701,380.55 \\
\text { zlotys } \\
(9.5 \%)\end{array}$ & $\begin{array}{c}170,869,974.00 \\
\text { zlotys } \\
(11.2 \%)\end{array}$ \\
\hline & $\begin{array}{l}\text { PRIORITY II: } \\
\text { Strengthening } \\
\text { human resources } \\
\text { development in } \\
\text { regions }\end{array}$ & $\begin{array}{l}\text { 2.1 Development of } \\
\text { competencies linked to } \\
\text { the regional labour } \\
\text { market needs and } \\
\text { lifelong learning } \\
\text { opportunities }\end{array}$ & $\begin{array}{c}37 \\
(4.7 \%)\end{array}$ & $\begin{array}{l}25,367,883.31 \\
\text { zlotys } \\
(2.6 \%)\end{array}$ & $\begin{array}{l}32,821,323.01 \\
\text { zlotys } \\
(2.1 \%)\end{array}$ \\
\hline & & $\begin{array}{l}\text { 2.2 Equalising the } \\
\text { educational opportunities } \\
\text { through scholarship } \\
\text { programmes } \\
\text { 2.2.1 Support for educational } \\
\text { development of rural youth } \\
\text { 2.2.2 Support for educational } \\
\text { development of student }\end{array}$ & $\begin{array}{c}223 \\
(28.4 \%)\end{array}$ & $\begin{array}{l}51,103,062.96 \\
\text { zlotys } \\
(5.3 \%)\end{array}$ & $\begin{array}{c}74,184,625.63 \\
\text { zlotys } \\
(4.8 \%)\end{array}$ \\
\hline & & $\begin{array}{l}2.3 \text { Vocational } \\
\text { reorientation of persons } \\
\text { leaving agricultural } \\
\text { sector }\end{array}$ & $\begin{array}{c}18 \\
(2.3 \%)\end{array}$ & $\begin{array}{l}13,842,663.04 \\
\text { zlotys } \\
(1.4 \%)\end{array}$ & $\begin{array}{l}18,704,343.81 \\
\text { zlotys } \\
(1.2 \%)\end{array}$ \\
\hline & & $\begin{array}{l}2.4 \text { Vocational } \\
\text { reorientation of } \\
\text { workforce affected by } \\
\text { restructuring processes }\end{array}$ & $\begin{array}{c}24 \\
(3.1 \%)\end{array}$ & $\begin{array}{c}19,373,633.41 \\
\text { zlotys } \\
(2.0 \%)\end{array}$ & $\begin{array}{c}27,354,465.35 \\
\text { zlotys } \\
(1.8 \%)\end{array}$ \\
\hline
\end{tabular}


Tabela $2 \mathrm{~cd}$.

\begin{tabular}{|c|c|c|c|c|c|}
\hline $\begin{array}{l}\text { Dimension } \\
\text { of cohesion }\end{array}$ & PRIORITY & Measure / Sub-measure & $\begin{array}{l}\text { No. of } \\
\text { projects }\end{array}$ & $\begin{array}{l}\text { Co-financing } \\
\text { from structural } \\
\text { funds }\end{array}$ & $\begin{array}{l}\text { Total value of } \\
\text { projects }\end{array}$ \\
\hline & & $\begin{array}{l}2.5 \text { Entrepreneurship } \\
\text { promotion }\end{array}$ & $\begin{array}{c}16 \\
(2.0 \%)\end{array}$ & $\begin{array}{c}10,538,682.06 \\
\text { zlotys } \\
(1.1 \%)\end{array}$ & $\begin{array}{c}17,364,105.59 \text { zlo- } \\
\text { tys } \\
(1.1 \%)\end{array}$ \\
\hline & $\begin{array}{l}\text { PRIORITY III: } \\
\text { Local development }\end{array}$ & 3.1 Rural areas & $\begin{array}{c}107 \\
(13.5 \%)\end{array}$ & $\begin{array}{c}121,371,985.70 \\
\text { zlotys } \\
(12.6 \%)\end{array}$ & $\begin{array}{c}176,580,660.20 \\
\text { zlotys } \\
(11.6 \%)\end{array}$ \\
\hline & & $\begin{array}{l}\text { 3.5 Local social infra- } \\
\text { structure } \\
\text { 3.5.1 Local sports and educa- } \\
\text { tional infrastructure } \\
\text { 3.5.2 Local health-care infra- } \\
\text { structure }\end{array}$ & $\begin{array}{c}21 \\
(2.7 \%)\end{array}$ & $\begin{array}{l}37,452,475.34 \\
\text { zlotys } \\
(3.9 \%)\end{array}$ & $\begin{array}{l}61,237,512.90 \\
\text { zlotys } \\
(4.0 \%)\end{array}$ \\
\hline TOTAL: & & & $\begin{array}{c}493 \\
(62,7 \%)\end{array}$ & $\begin{array}{c}75661694,69 \\
\text { zlotys } \\
(49,6 \%) \\
\end{array}$ & $\begin{array}{c}749259998,30 \\
\text { zlotys } \\
(49,0 \%) \\
\end{array}$ \\
\hline Territorial & $\begin{array}{l}\text { PRIORITY I: } \\
\text { Development and } \\
\text { modernisation of } \\
\text { the infrastructure } \\
\text { to enhance the } \\
\text { competitiveness of } \\
\text { regions }\end{array}$ & $\begin{array}{l}\text { 1.1. Modernisation and } \\
\text { expansion of the regional } \\
\text { transport system } \\
\text { 1.1.1 Road infrustructure } \\
\text { 1.1.2 Public transport infra- } \\
\text { structure }\end{array}$ & $\begin{array}{c}55 \\
(7,0 \%)\end{array}$ & $\begin{array}{c}316159966,35 \\
\text { zlotys } \\
(33,0 \%)\end{array}$ & $\begin{array}{c}490235782,47 \\
\text { zlotys } \\
(32,0 \%)\end{array}$ \\
\hline & & $\begin{array}{l}\text { 1.5. Information society } \\
\text { infrastructure }\end{array}$ & $\begin{array}{c}4 \\
(0,5 \%)\end{array}$ & $\begin{array}{c}10493388,19 \\
\text { zlotys } \\
(1,1 \%) \\
\end{array}$ & $\begin{array}{c}14733732,30 \\
\text { zlotys } \\
(1,0 \%) \\
\end{array}$ \\
\hline & & $\begin{array}{l}\text { 1.6. Public transport } \\
\text { development in the } \\
\text { agglomeration }\end{array}$ & $\begin{array}{c}4 \\
(0,5 \%)\end{array}$ & $\begin{array}{c}37460782,42 \\
\text { zlotys } \\
(3,8 \%) \\
\end{array}$ & $\begin{array}{c}75043635,16 \text { zlo- } \\
\text { tys } \\
(4,9 \%)\end{array}$ \\
\hline & $\begin{array}{l}\text { PRIORITY III: } \\
\text { Local development }\end{array}$ & $\begin{array}{l}3.2 \text { Areas undergoing } \\
\text { restructuring }\end{array}$ & $\begin{array}{c}7 \\
(0,9 \%)\end{array}$ & $\begin{array}{c}9251454,28 \\
\text { zlotys } \\
(1,0 \%)\end{array}$ & $\begin{array}{c}15285675,58 \\
\text { zlotys } \\
(1,0 \%)\end{array}$ \\
\hline & & $\begin{array}{l}\text { 3.3 Degraded urban, } \\
\text { post-industrial and post- } \\
\text { military sites } \\
\text { 3.3.1 Revitalisation of urban } \\
\text { sites } \\
\text { 3.3.2 Revitalisation of post- } \\
\text { industrial and post-military } \\
\text { sites }\end{array}$ & $\begin{array}{c}6 \\
(0,8 \%)\end{array}$ & $\begin{array}{c}15034760,08 \\
\text { zlotys } \\
(1,6 \%)\end{array}$ & $\begin{array}{c}21890498,20 \\
\text { zlotys } \\
(1,4 \%)\end{array}$ \\
\hline \multicolumn{3}{|l|}{ TOTAL: } & $\begin{array}{c}76 \\
(9,7 \%)\end{array}$ & $\begin{array}{c}388400351,32 \\
\text { zlotys } \\
(40,5 \%) \\
\end{array}$ & $\begin{array}{c}617189323,71 \\
\text { zlotys } \\
(40,3 \%) \\
\end{array}$ \\
\hline \multicolumn{3}{|c|}{ GRAND TOTAL } & $\begin{array}{c}786 \\
(100,0 \%)\end{array}$ & $\begin{array}{c}958873689,28 \\
\text { zlotys } \\
(100,0 \%)\end{array}$ & $\begin{array}{c}1530140180,21 \\
\text { zlotys } \\
(100,0 \%)\end{array}$ \\
\hline
\end{tabular}

* In the case of PRIORITY II, as of June 30th 2009.

Source: own study based on the the unpublished resources of the Marshal Office of the Wielkopolska Region. 
an intervention granted which should appear as a simple consequence of the undertaking. An interim result is the mid-term effect of the intervention envisaged in the Operational Programme concerned and generated by its direct results. A long-term result is the positive influence of the interim results of each diagnostic measure on the relevant dimension of cohesion. These assumptions lead to the building of a logical model for each diagnosed measure implemented within the IROP framework in Wielkopolska based on the following research hypothesis: If the direct results of an intervention produce the interim results assumed, and the interim results improve the relevant dimension of cohesion, then the intervention can be judged to contribute to the improvement of the relevant dimension of cohesion, and thus the interim results allow accomplishing the long-term results ${ }^{11}$. In order to verify this hypothesis and determine the interaction between the investigated results which describes the effectiveness of the intervention, regression models were applied ${ }^{12}$. The results were described using indicators of socio-economic dynamics in the years 2003-2008 in the communes of Wielkopolska voivodeship (in the case of economic and social cohesion) and Wielkopolska poviats (in the case of territorial cohesion). The selection of indicators was seriously limited by the accessibility of statistical data and forced the authors to make far-reaching compromises and simplifications concerning the initially planned scope of the analytical procedure. The interdependencies occurring between the results of intervention were described for each dimension of cohesion and each diagnostic measure with the help of two regression models. In the first case, a model of multiple regression determines the relation between the direct results (predictors) and the assumed interim result (dependent variable). Thanks to the quasi-experimental design and difference-in-differences technique used for each

11 The determination of direct results is based on measures implemented under the IROP in Wielkopolska (2004), the selection of interim result is consistent with the IROP 2004 assumptions for each measure analysed, whereas long-term results are assessed in terms of the conception of the three dimensions of cohesion presented in this paper.

${ }^{12}$ All calculations were made with use of the SPSS software. The authors would like to thank Dr Tomasz Kossowski, who greatly contributed to the mathematical aspect of this article. diagnostic measure, there is a control group of communes/poviats which have not participated in the intervention and an experimental group of units that have implemented the measure (Card \& Krueger 1994; Morton 2009). Due to the great differences in the number of units belonging to the control and the experimental group, randomisation was applied to increase the reliability of the results. In the second step, a simple linear regression model identifies the level of influence of the interim result (predictor) on the improvement of the relevant dimension of cohesion (dependent variable). The analysis of this relation is conducted for the population of all communes (in the case of economic and social cohesions) or poviats (in the case of territorial cohesion) of Wielkopolska voivodeship (see Table 3).

\section{Economic cohesion}

The analysis of the effectiveness of structural funds interventions implemented in the period 2004-2006 in Wielkopolska to improve its economic cohesion was conducted for two IROP measures.

When the volume of outlays was considered, the analysis included Measure 1.4, Development of tourism and culture, with its share of $8.9 \%$ of available funding and the total value of implemented projects of 115.2 million zlotys (25.8 million euros). Under this intervention, 18 projects were implemented in Wielkopolska among which infrastructural undertakings predominated; they accounted for nearly $70 \%$ of the applications approved. They mostly focused on revitalisation of historic objects, since this was the objective of more than a half of the selected projects. Considering the direction of the intervention and access to statistical data, the direct results of Measure 1.4 were described with the help of three indicators reflecting the magnitude of change in domestic and international tourist traffic as well as changes in the state of infrastructure related to cultural facilities and national heritage objects in the period 2003-2008 (predictors). In addition to the variables characterising the expected direct results, a dummy variable was employed in the model which took the value of 0 or 1 depending on whether or not the analysed unit participated 
in the intervention. On the basis of the objectives listed for Measure 1.4 in the IROP ${ }^{13}$, it was assumed that in a mid-term perspective this intervention should contribute to the development of the hotel and restaurant industries. Accordingly, an interim result of spending on Measure 1.4 would be a change in employment in that sector (dependent variable). Because of a considerable concentration of funding in a few communes ${ }^{14}$, a quasi-experimental design and the randomisation procedure were employed to analyse the relationships between the direct and the interim results by comparing the six-element experimental group with six randomly chosen elements of the control group. The analysis of the effect of direct results on the anticipated interim result was carried using multiple regression (see Table 3). Its results lead to the conclusion that the only significantly influence on employment in the hotel and restaurant industries was the very fact of implementation of projects under Measure 1.4, Development of tourism and culture. Having identified the impact of the intervention on the interim result, an attempt was made to determine its effect on economic cohesion (long-term result), and the indicator employed to describe it was changes in the communes' own income in the years 2003-2008. The linear regression model showed that the changes in employment in the hotel and restaurant sector (interim result) had brought about significantly changes in the communes' own income (long-term result). It should be observed, however, that the estimated model is characterised by a very low coefficient of determination, which means that in the set of the 226 Wielkopolska communes there may also be other factors influencing the dependent variable beside those included in the model, disregarded because of the lack of statistical data.

A similar research procedure was conducted for the other IROP measure, which according to the authors' opinion should be potentially

${ }^{13}$ There were four specific objectives identified under Measure 1.4: (1) increase in the role of culture and tourism as factors stimulating the socio-economic development of the region while ensuring it sustainable development and environmental protection; (2) better access to tourist and cultural attractions and facilities; (3) lengthening of the tourist season; and (4) increase in the influx of tourists from abroad and domestic ones.

${ }^{14}$ Half of the projects implemented under Measure 1.4 were carried out in the city of Poznan. the strongest in improving economic cohesion. This was Measure 3.4, Micro-enterprises, with its share in the total allocation of the IROP funding of $1.1 \%$, a total value amounting to 32.8 million zlotys (7.3 million euros), and 156 projects implemented in Wielkopolska, all of them involving investment in fixed assets. Given the assumptions of the operational programme and the statistical data available, the direct results of this intervention were taken to be changes in the number of micro-enterprises and their employment in the period 2003-2008 (predictors). Since there was no possibility of collecting data picturing a change in their turnover, the interim result was not identified for further analysis; it was taken to be identical with the long-term result, viz. changes in the communes' own income over 2003-2008 (dependent variable). As before, the dependence between the direct and the interim results ${ }^{15}$ was examined using the model of multiple regression in which the independent variables included a dummy variable determining whether or not intervention was granted (see Table 3). The obtained results lead to the conclusion that both, the change in employment in micro-enterprises and the very fact of structural funds intervention exert a significant influence on the improvement of the economic cohesion of the region as reflected in changes in its communes' own income. An analysis of the correlation between the predicting variables revealed that these two directions of influence are independent of each other, i.e. there is no statistical relation between employment and the public aid granted. This results from the investment type of the projects selected for implementation, which did not succeed in boosting employment in micro-enterprises over the short time studied. It has to be noted that the estimated model is characterised by a very low coefficient of determination, which indicates the existence of other factors enhancing economic cohesion in the intraregional system of Wielkopolska. Regrettably, the scant resources of data available at the region's LAU-2 level make the identification of those relations impossible.

\footnotetext{
${ }^{15}$ In this case identical with the long-term result.
} 
TAble 3. Evaluation of EFFectiveness of IROP 2004-2006 INTERVENTIONS IN WielKOPOLSKA VOIVODESHIP - DiAGNOSTIC MEASURES IN THREE DIMENSIONS OF COHESION WITH INDICATORS AND REGRESSION MODELS

\begin{tabular}{|c|c|c|}
\hline $\begin{array}{l}\text { Dimension } \\
\text { of cohesion }\end{array}$ & PRIORITY / Measure by input volume & $\begin{array}{l}\text { PRIORITY / Measure by highest } \\
\text { assumed influence on cohesion }\end{array}$ \\
\hline Economic & 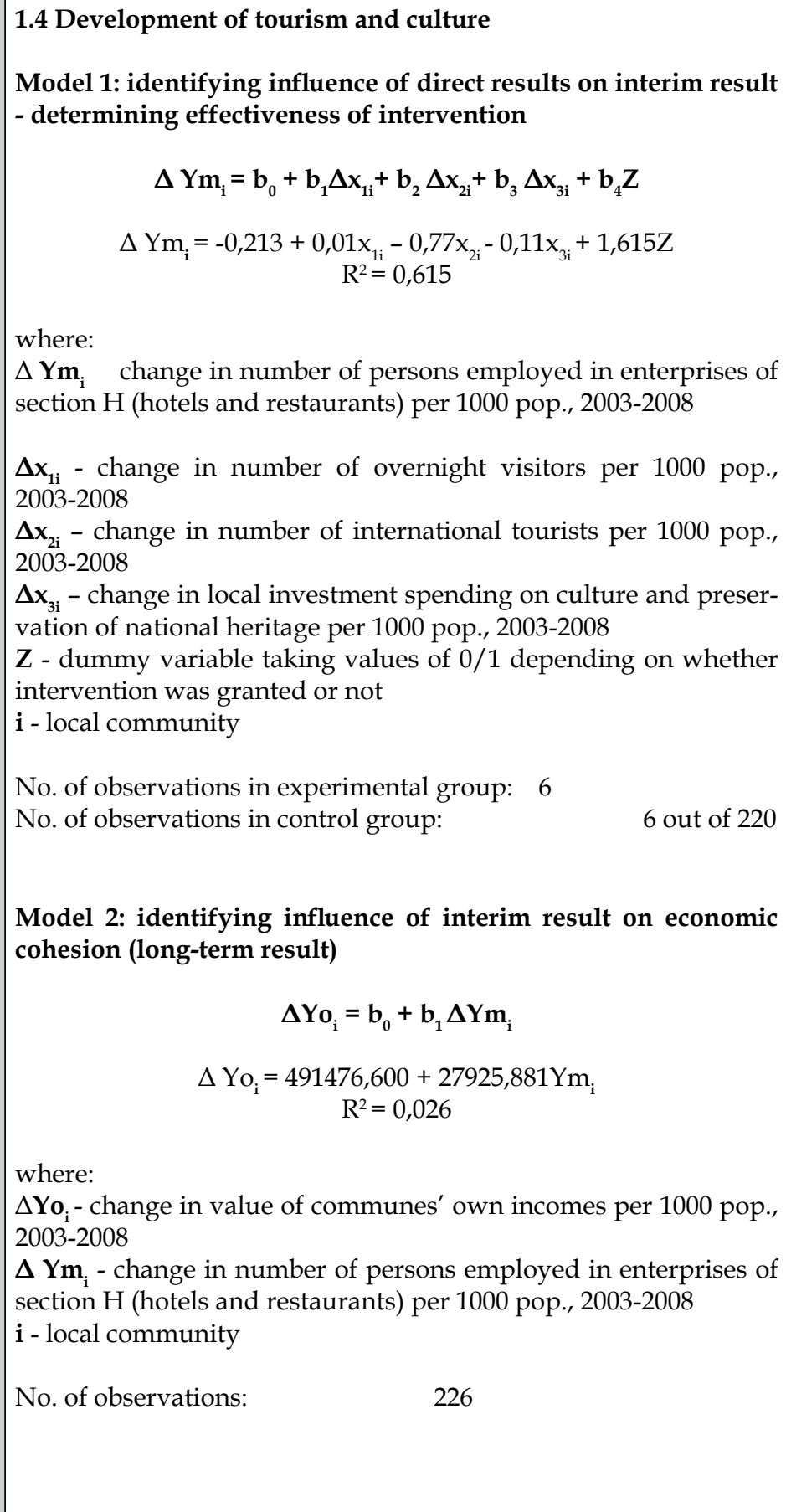 & 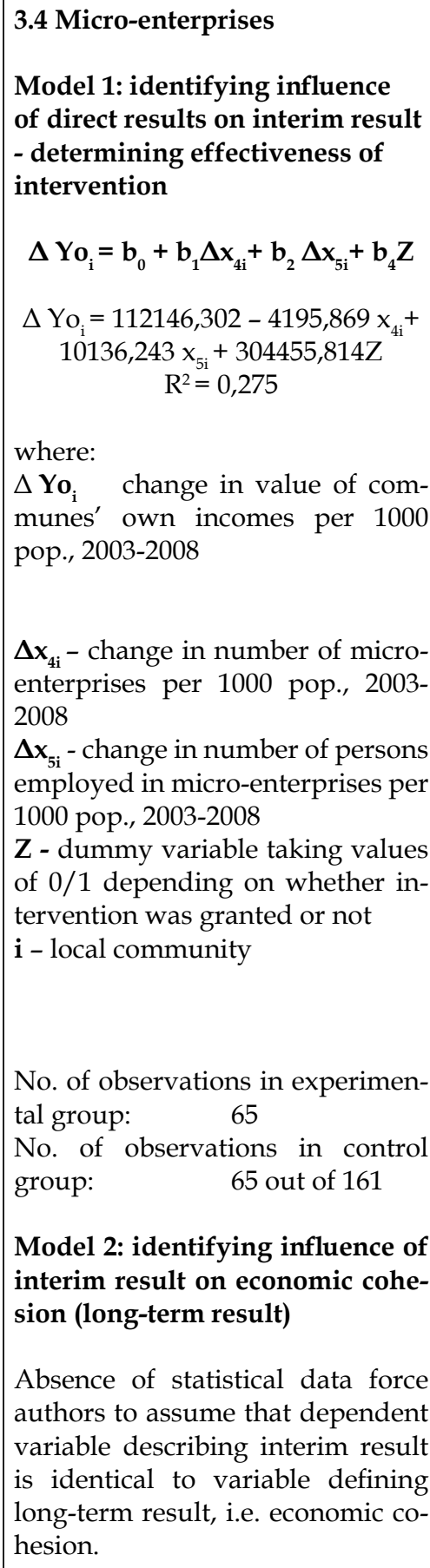 \\
\hline
\end{tabular}


Tabela $3 \mathrm{~cd}$

\begin{tabular}{|c|c|c|}
\hline $\begin{array}{l}\text { Dimension } \\
\text { of cohesion }\end{array}$ & PRIORITY / Measure by input volume & $\begin{array}{l}\text { PRIORITY / Measure by highest } \\
\text { assumed influence on cohesion }\end{array}$ \\
\hline Social & 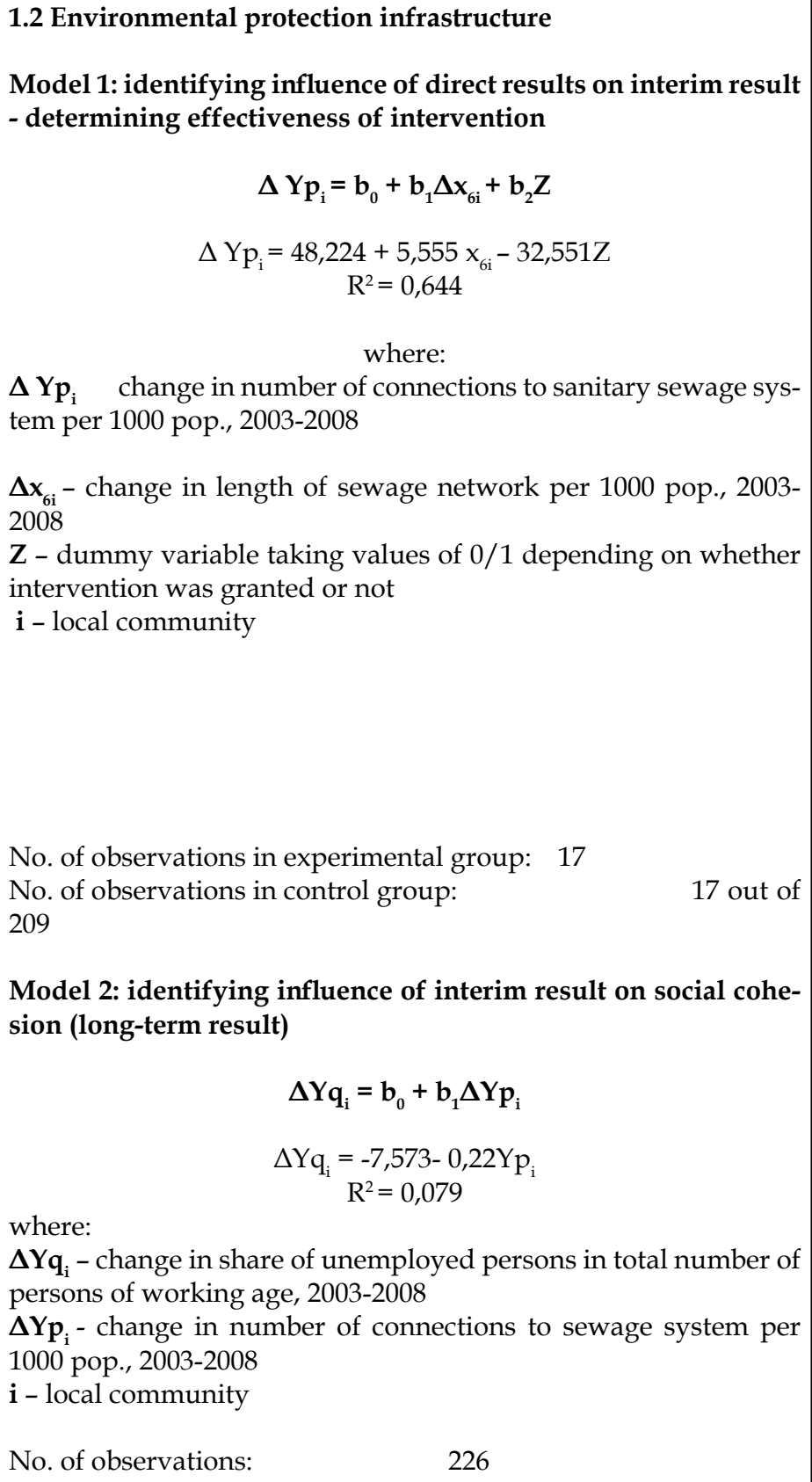 & 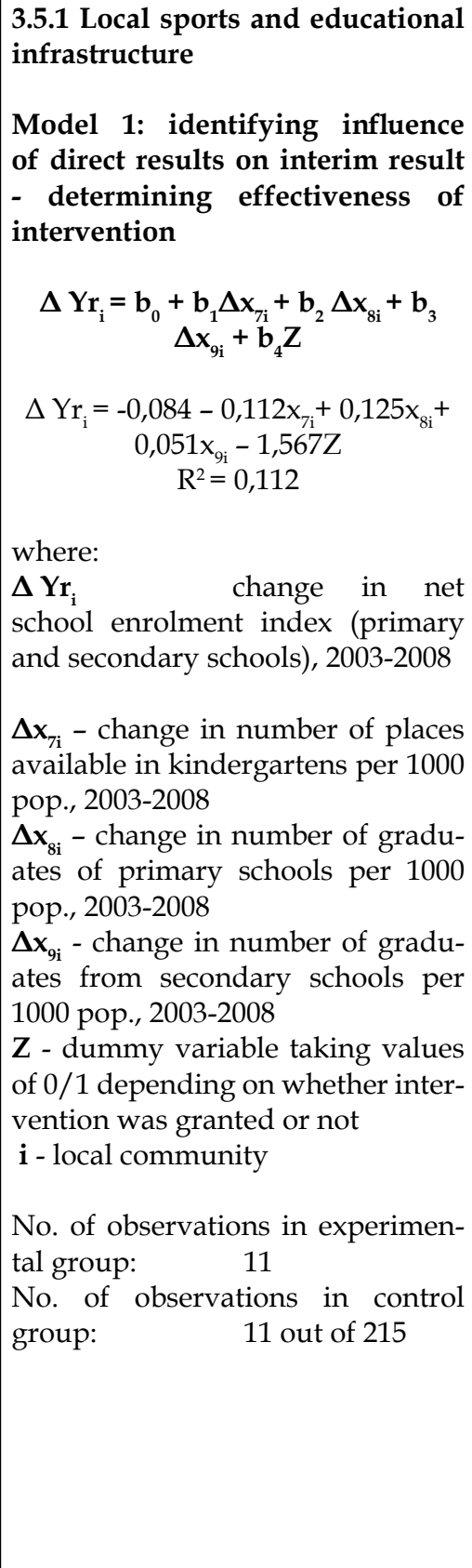 \\
\hline
\end{tabular}




\begin{tabular}{|c|c|c|}
\hline $\begin{array}{l}\text { Dimension } \\
\text { of cohesion }\end{array}$ & PRIORITY / Measure by input volume & $\begin{array}{l}\text { PRIORITY / Measure by highest } \\
\text { assumed influence on cohesion }\end{array}$ \\
\hline \multirow[t]{2}{*}{ Territorial } & 1.1.1 Road infrastructure & 1.1.1 Road infrastructure \\
\hline & \multicolumn{2}{|c|}{ 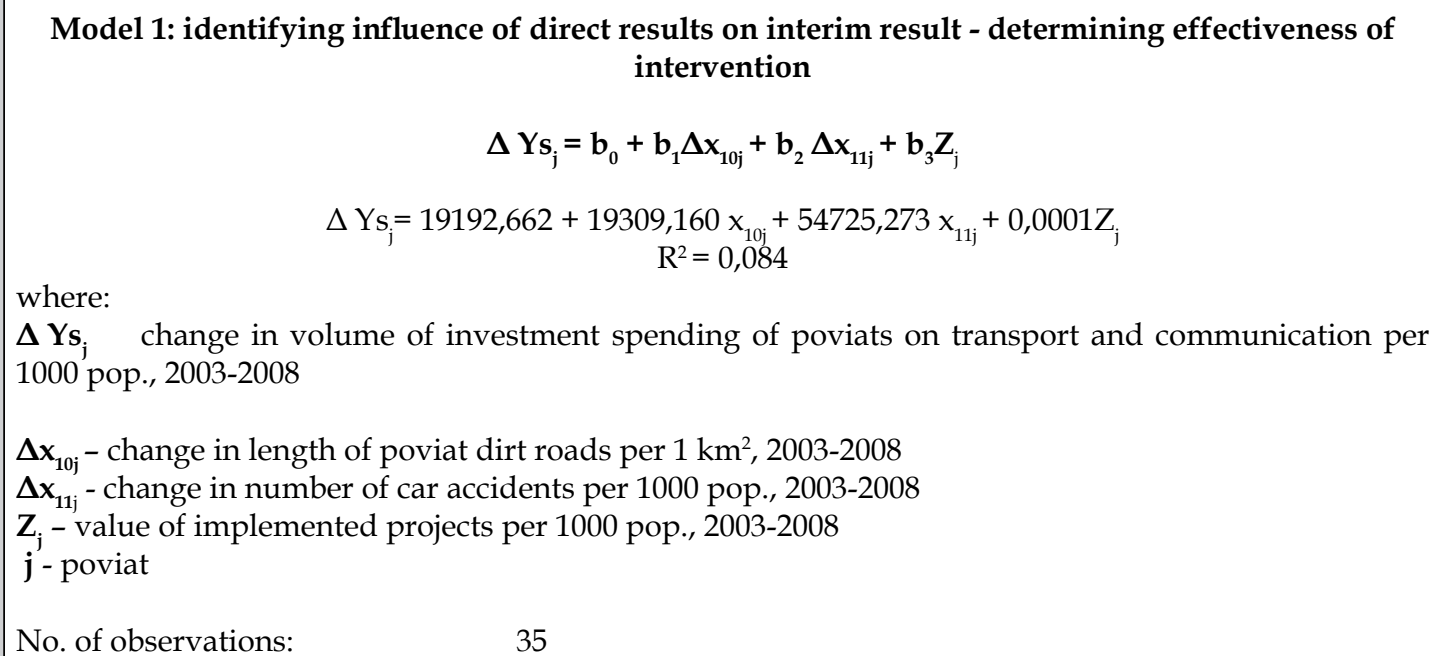 } \\
\hline
\end{tabular}

Source: own calculations on the basis of the Integrated Regional Operational Programme (2004).

\section{Social cohesion}

The analysis of the effectiveness of IROP intervention in improving social cohesion was made again for the measure with the highest funding and the measure with potentially the highest influence on this type of cohesion.

Among all the measures improving the social cohesion of Wielkopolska in the analysed period, the highest financial means went to Measure 1.2, Environmental protection infrastructure. Its share in the allocation amounted to $12.2 \%$ and the total value of projects was 170 million zlotys (38 million euros). While the objectives of this intervention included several directions ${ }^{16}$, nearly $95 \%$ of the 19 projects implemented in Wielkopolska concerned the construction and modernisation of wastewater collection networks and wastewater treatment plants contributing to an improvement

${ }^{16}$ The IROP set up the following specific objectives under Measure 1.2: (1) limiting pollution emitted to the air, water and soil; (2) improving flood-risk management; (3) increasing the use of renewable energy sources; and (4) improving environmental management. in the inhabitants' standards of living. This fact affected the selection of indicators for direct results: the only variable chosen was the change in the state of the water and sewage system for the period 2003-2008 (predictor). In accordance with the general IROP assumptions, the interim result was defined as a change in connections to the sewerage system. The estimated model of multiple regression identified a significant causal relationship between the interim result and both the intervention co-financed from the Structural Funds and the direct result (see Table 3). Because of the effect of the intervention on the interim result, an analysis was also made of how it improved social cohesion at the local level (long-term result) as indicated by a change in the unemployment rate. The result confirmed the significant influence of the interim result of Measure 1.2, Environmental protection infrastructure, on the long-term one in the Wielkopolska communes. However, the estimated model has a very low coefficient of determination, which suggests the existence of other factors potentially influencing the region's social cohesion but impossible to identify in the mathematical analysis due to limitations in data accessibility. 
The diagnostic measure chosen for further analysis with respect to the anticipated highest influence of structural funds intervention on improving the social cohesion of Wielkopolska is Sub-measure 3.5.1, Local sports and educational infrastructure, a component of Measure 3.5, Local social infrastructure ${ }^{17}$. The total value of projects launched under this sub-measure amounted to 43 million zlotys (9.6 million euros), or $4 \%$ of the IROP allocation in Wielkopolska. A total of 14 projects were implemented in the region in the perspective 2004-2006 involving the construction or modernisation of primary and lower-secondary schools (over $70 \%$ of projects), upper-secondary secondary schools (over $20 \%$ ), and kindergartens (under 10\%). The indicators of the direct results of this sub-measure were a change in the number of graduates of primary and lower-secondary schools and a change in kindergarten infrastructure in the years 2003-2008. The analysis of their influence on the interim result, defined under the IROP objectives as a change in school enrolment $^{18}$, rested again on a multiple regression model (see Table 3). The obtained results showed none of the predictors to have a significant influence on the assumed interim result. On the one hand, this may be due to the choice of descriptive indicators, reduced to the statistical data available, which apparently do not include those significantly affecting the interim and long-term results of the intervention. On the other hand, this outcome may be a consequence of the time lag typical of the results of intervention shaping social cohesion ${ }^{19}$. It is therefore recommended to continue this research, which can be considered a full ex-post evaluation study of its interim and long-term results only from the perspective of several years after its completion. Lack of a significant dependence between the intervention and its interim result was the reason why inves-

${ }^{17}$ Measure 3.5, Local social infrastructure, was composed of two sub-measures: 3.5.1, Local sports and educational infrastructure, and 3.5.2, Local health-care infrastructure. Because it was necessary to determine the cause-andeffect interdependences as reflected in the relationship between various categories of results, it was impossible to subject both sub-measures to common analysis.

${ }^{18}$ Considered jointly for primary and lower-secondary schools.

${ }^{19}$ The period covered by the analysis ends on December $31^{\text {st }}, 2008$ (the latest data available for LAU-2 units), which makes it impossible to identify those results. tigating the causal relationship between the interim and the long-term result was given up.

\section{Territorial cohesion}

The analysis of the effectiveness of IROP structural funds intervention aiming at improving territorial cohesion was conducted for Submeasure 1.1.1, Road infrastructure, classified as a measure with both, the highest share in the allocated financial resources $(16 \%$ of IROP funding) and the highest potential influence on territorial cohesion. It accounted for 35 projects worth a total of 320 million zlotys (71.6 million euros) launched in Wielkopolska in the perspective 2004-2006. The support concerned the construction and modernisation of vital components of the regional transportation system: commune, poviat, and voivodeship roads, improving traffic security and access to national and international road networks, regional economic centres, and the existing or planned industrial and service facilities. Lack of statistical data forced the authors to consider the relation between the results of this intervention at the poviat level (LAU-1), unlike in the former cases of economic and social cohesion where the results were considered at the commune level (LAU-2). The direct results were assumed to be a change in road density and traffic security (predictors). The interim result, in accordance with the IROP objectives, was defined as a change in poviats' investment spending on transport during the period 2003-2008 (dependent variable). Because of the small size of the analysed population (projects were only implemented in 5 out of the 35 Wielkopolska poviats), the randomisation procedure was not applied and the dummy variable was replaced with the indicator of a project value (see Table 3). The multiple regression model showed no significant influence exercised by any of predictors on the assumed interim result, i.e. investment spending on transport in the poviats. This proves that there is no relationship between the main directions of structural funding and the relevant budget items of self-governments at the poviat level, which may be attributed to inadequate development of the match-funding mechanism, especially in the field of application of the subsidiarity rule. How- 
ever, absence of relevant statistical data makes it impossible to investigate other regularities. Lack of a significant dependence between the intervention and its interim result was the reason why investigating the causal relationship between the interim result and territorial cohesion (long-term result) was given up.

\section{Conclusions}

The above analysis shows there to be serious objective obstacles to conducting an evaluation of the effectiveness of the structural funds intervention granted at the local level in Poland. Meeting the challenges facing regional policy evaluation presented in this article and conducting it on the basis of the concept of three dimensions of cohesion are made nearly impossible due to limitations in the accessibility of statistical data. The attempt to analyse the intraregional system of Wielkopolska voivodeship leads to the following recommendations:

1. The results of the empirical analysis reveal problems with the selection of statistical indicators assessing direct, interim and long-term results of public intervention granted. The absence of the necessary statistical data, especially at the local level, creates a barrier to an objective assessment of the effectiveness and efficiency of regional policy measures implemented in Poland. The range of the available secondary data prevents the use of the presented method relying on a quasi-experimental design and the differencein-differences technique, the two tools strongly recommended for evaluating the effectiveness and efficiency of cohesion policy after 2013.

2. Regional policy is a unique public policy conducted in a multilevel governance system where the regional and the local level play a special role. Therefore, immediate steps should be taken to ensure conditions for a reliable assessment of its results in those spatial systems. Regional statistics should answer the needs emerging from the new, post-2004 conditions of the state's operation, i.e. after the accession of Poland to the EU. It is obvious that, in the situation of neglect on the part of the Central Statistical Office, the Ministry of Regional Development should play a crucial role in adjusting the methodology of statistical data collection so as to make them useful in intervention analyses.

3. The obtained results lead to the conclusion that this research should be continued relying on three assumptions:

- an attempt should be made to complement the secondary data with primary data, which will help to make a better choice of indicators describing the results of public intervention;

- the research should be continued in the years to come due to a chance of capturing the influence of direct and interim results of intervention on its long-term results; and

- a similar research should be conducted for the population of all the spatial units in Poland since some of the statistical deficiencies exposed in the analysis could have resulted from too small a size of the sample of units - beneficiaries of IROP-financed public intervention in Wielkopolska in the period 2004-2006.

\section{References}

Alkin M.C., 2004. Evaluation roots: Tracing theorists' views and influences. Sage Publications, Newbury Park.

BACHTLER J., 2008. Ewaluacja regionalnej polityki w Europie: kultura, zaangażowanie i potencjał (Evaluation of regional policy in Europe: culture, involvement and potential). In: K. Olejniczak (ed.), 2008. Teoria i praktyka ewaluacji interwencji publicznych: podręcznik akademicki. Wydawnictwa Akademickie i Profesjonalne, Warszawa.

BACHTLER J. \& WREN C., 2006. Evaluation of European Union Cohesion policy: Research questions and policy challenges. Regional Studies, 40 (2): 143-153.

BARCA F., 2009. An Agenda for a Reformed Cohesion Policy. A place-based approach to meeting European Union challenges and expectations. Independent Report.

Cards D. \& Krueger A.B., 1994. Minimum wages and employment: A case study of the fast-food industry in New Jersey and Pennsylvania. American Economic Review, September, 84 (4): 772-793.

CHEN H.T., 1990. Theory-driven evaluations. Sage Publications, Newbury Park.

Churski P., 2008. Czynniki rozwoju regionalnego i polityka regionalna $w$ Polsce w okresie integracji $z$ Uniq Europejska (Factors of regional development and regional policy in Poland in the period of integration with the European Union), Seria Geografia nr 79, Wydawnictwo Naukowe UAM, Poznań.

Churski P. (ed.), 2009a. Spójność i konkurencyjność regionu wielkopolskiego. Wyniki projektu badawczego zrealizowanego w ramach konkursu dotacji Ministerstwa Rozwoju Regionalnego w zakresie wdrażania funduszy strukturalnych na poziomie Narodowej Strategii Spójności (Cohesion and com- 
petitiveness of the Wielkopolska region) Umowa: DKS/ DEFVIII/POPT/04/275/09. Wersja CD. Poznań: 734.

CHURSKi P., 2009b. Polityka regionalna a kształtowanie się spójności i konkurencyjności Wielkopolski (Regional policy and shaping cohesion and competitiveness in Wielkopolska). In: P. Churski (ed.), Spójność $i$ konkurencyjność regionu wielkopolskiego. Wyniki projektu badawczego zrealizowanego w ramach konkursu dotacji Ministerstwa Rozwoju Regionalnego w zakresie wdrażania funduszy strukturalnych na poziomie Narodowej Strategii Spójności. Umowa: DKS/DEF-VIII/POPT/04/275/09. Wersja CD. Poznań: 197.

CHURSKI P., 2009c. Polityka regionalna w okresie 2004-2006 a spójność i konkurencyjność Wielkopolski (Regional policy in the years 2004-2006 and cohesion and competitiveness in Wielkopolska). In: T. Czyż (ed.), Regionalny wymiar województwa wielkopolskiego. Biuletyn Instytutu Geografii Społeczno - Ekonomicznej i Gospodarki Przestrzennej UAM. Seria Rozwój Regionalny i Polityka Regionalna nr 9: 101-133.

ChURSKI P., 2010. Regional policy and the development of the cohesion and competitiveness of Wielkopolska in 2004-2006. In: P. Churski, W. Ratajczak (eds), Regional development and regional policy in Poland: First experiences and new challenges of the European Union membership. Studia Regionalia, 27 (forthcoming).

Community Support Framework. Promoting economic growth and an environment for job creation, 2003. European Commission, Brussels-Warsaw.

Diagnoza stanu województwa - II Etap. Strategia rozwoju Wielkopolski (Diagnosis of the state of the voivodeship - Stage II. Development strategies for Wielkopolska), 1999. Urząd Marszałkowski Województwa Wielkopolskiego, Poznań.

DutKOwSKi M., 2008. Problemy ewaluacji polityki regionalnej (Problems of regional policy evaluation). In: T. Stryjakiewicz, T. Czyż (eds), O nowy kształt badań regionalnych $w$ geografii $i$ gospodarce przestrzennej. Biuletyn Komitetu Przestrzennego Zagospodarowania Kraju, 237: 36-49.

Europa 2020. Strategia na rzecz inteligentnego i zrównoważonego rozwoju sprzyjającego włączeniu społecznemu. (Europe 2020: A strategy for smart, sustainable and inclusive growth). Komunikat Komisji. COM (2005) 2020. 3.03.2010. Brussels.

European Commission, 2007. Evalsed - the resource for the evaluation of the socio-economic development. GUIDE Annex B - Changes in Structural Funds regulations. Retrieved May 6, 2010, from http://ec.europa.eu/regional_policy/sources/docgener/evaluation/evalsed/guide/ annex_b/index_en.htm

FALUDI A., 2006. From European spatial development to territorial cohesion policy. Regional Studies, 40 (6): 667-678.

GoRzELAK G., 2009. Fakty i mity rozwoju regionalnego (Facts and myths of regional development). Studia Regionalne i Lokalne, 2(36): 5-27.

GorzelaK G. \& JAŁOWIECKI B. 2001. Strategie rozwoju regionalnego województw: próba oceny (Strategies of the regional development of voivodeships: An assessment). Studia Regionalne i Lokalne,1 (5): 41-60.
Green Paper on Territorial Cohesion. European Commission, October 2008. Brussels.

Growing Regions, Growing Europe, 2007. European Commission, Fourth Report on Economic and Social Cohesion, Brussels.

HỬBNER D., 2008. Spójność i konkurencyjność - czy można je połączyć (Cohesion and competitiveness - can they be combined?). Paper presented at the 4th Congress of the Polish Lisbon Strategy Forum. Warszawa. Retrieved October 13, 2006, from http:/ / www.strategializbonska.pl/

KARWACKI A., 2009. Spójność - kluczowe pojęcie dla współczesnej polityki społecznej (inspiracje, tropy i wyzwania) (Cohesion - a key term for a modern social policy - inspirations, traces and challenges). Studia Socjologiczne, 1/2009(192): 9-51.

KIERZKOWSKI T., 2002. Ocena (ewaluacja) programów i projektów o charakterze społeczno-gospodarczym w kontekście przystąpienia Polski do Unii Europejskiej (Evaluation of socio-economic programmes and projects in the context of Polish accession to the EU). Polska Agencja Rozwoju Przedsiębiorczości, Warszawa.

KUKLIŃSKI A., 2003. O nowym modelu polityki regionalnej - artykuł dyskusyjny (About a new model of regional policy). Studia Regionalne i Lokalne, 4 (14): 15-15.

Marszat T. \& PielesiaK I., 2008. Spójność obszaru metropolitalnego $\mathrm{w}$ świetle powiązań infrastrukturalnych (przykład Łódzkiego Obszaru Metropolitalnego) (Cohesion of metropolitan areas in the light of infrastructural connections - the example of the Łódź Metropolitan Area), Studia Komitetu Przestrzennego Zagospodarowania Kraju PAN, 70: 180-196.

Morton M.H, 2009. Applicability of Impact Evaluation to Cohesion Policy. In: F. Barca (ed.), An Agenda for a Reformed Cohesion Policy. A place-based approach to meeting European Union challenges and expectations. Independent Report.

Narodowy Plan Rozwoju 2004-2006 (National Development Plan 2004-2006). Komitet Rady Ministrów. Styczeń 2003. Warszawa.

OlejNiczAK K., 2007. Teoretyczne podstawy ewaluacji expost (Theoretical foundations of ex-post evaluation). In: A. Haber (ed.), Ewaluacja ex-post. Teoria i praktyka badawcza. Polska Agencja Rozwoju Przedsiębiorczości, Warszawa.

OlejNiczAK K. (ed.), 2008. Teoria i praktyka ewaluacji interwencji publicznych: podręcznik akademicki. (Theory and practice of evaluation of public interventions: An academic textbook). Wydawnictwa Akademickie i Profesjonalne, Warszawa.

OlejNicZAK K., 2009. Praktyka ewaluacji efektów programów rozwoju regionalnego - studium porównawcze. (Practice of evaluation of effects of regional programmes - a comaparative study). EUROREG, 2/2009, Warszawa.

Polityka spójności: Sprawozdanie strategiczne 2010 dotyczace realizacji programów na lata 2007-2013 (Cohesion policy: A strategic 2010 report on the implementation of 2007-2013 programmes). COM (2010) 110. 31.03.2010. Bruksela.

Polska wypada dobrze (Poland performs well). (2010, May 6). Rzeczpospolita. 
Reshaping Economic Geography. Word Development Report 2009. Word Bank, Washington.

SAMECKI P., 2009. Dokument kierunkowy dotyczacy przyszłej polityki spójności (Orientation paper on future cohesion policy). Bruksela.

SANDERS J., 1994. Joint Committee on Standards for educational evaluation. The program evaluation standards: How to assess evaluations of educational programs. Sage Publications: Newbury Park.

Shadish W. R., Cook T.C. \& Leviton L., 1991. Foundations of program evaluation: Theories of practice. Sage Publications, Newbury Park.

Stan wdrażania ZPORR w Wielkopolsce (State of implementing the IROP in Wielkopolska). Urząd Wojewódzki Województwa Wielkopolskiego. 2009. Poznań.

Sufflebeam D.L., Madaus G.F. \& Kellaghan T., 2000. Evaluation models: Viewpoints on educational and human services evaluation. Kluwer Academic Publishers, Norwell.
World Bank, 2008. Independent Evaluation Group - Overview. Retrieved May 6, 2010, from: http://www.worldbank. org/oed/ieg

Wykorzystanie ZPORR w województwie wielkopolskim w okresie 2004-2006. Stan w dniu 31 maja 2009r. (Absorption of the IROP funds in Wielkopolska in the years 2004-2006, as of $31^{\text {st }}$ May 2009). Ministerstwo Rozwoju Regionalnego. 2009. Warszawa.

Zintegrowany Program Operacyjny Rozwoju Regionalnego 2004-2006. Narodowy Plan Rozwoju 2004-2006. (Integrated Regional Operational Programme for the years 2004-2006. National Development Plan for the years 2004-2006). Ministerstwo Gospodarki, Pracy i Polityki Społecznej. February 2004. Warszawa.

Zintegrowany Program Operacyjny Rozwoju Regionalnego 20042006. Uzupetnienie Programu. (Integrated Regional Operational Programme for the years 2004-2006. Programme complement). Ministerstwo Gospodarki, Pracy i Polityki Społecznej. Warszawa. Marzec 2004. 